CURRENT REVIEW

\title{
Satellite RNAs and Satellite Viruses
}

\author{
Peter Palukaitis \\ Department of Horticultural Sciences, Seoul Women's University, 621 Hwarangno, Nowon-gu, Seoul, 139-774, Republic of \\ Korea
}

Submitted 14 October 2015. Accepted 5 November 2015.

\begin{abstract}
Satellite RNAs and satellite viruses are extraviral components that can affect either the pathogenicity, the accumulation, or both of their associated viruses while themselves being dependent on the associated viruses as helper viruses for their infection. Most of these satellite RNAs are noncoding RNAs, and in many cases, have been shown to alter the interaction of their helper viruses with their hosts. In only a few cases have the functions of these satellite RNAs in such interactions been studied in detail. In particular, work on the satellite RNAs of Cucumber mosaic virus and Turnip crinkle virus have provided novel insights into RNAs functioning as noncoding RNAs. These effects are described and potential roles for satellite RNAs in the processes involved in symptom intensification or attenuation are discussed. In most cases, models describing these roles involve some aspect of RNA silencing or its suppression, either directly or indirectly involving the particular satellite RNA.
\end{abstract}

Satellite RNAs and satellite viruses are supernumerary RNAs that depend on other viruses, referred to as helper viruses (HV), for their replication and movement (Briddon et al. 2012; Hu et al. 2009; Roossinck et al. 1992; Simon et al. 2004). Satellite RNAs and satellite viruses generally are unrelated in sequence to their HV. They are, in fact, parasites of parasites. Some of these have been shown to function as noncoding RNAs, vis-à-vis either interactions with host RNAs or interference between the HV and the host. Satellite RNAs and satellite viruses differ from each other in that the latter encode a protein that packages the eponymous satellite virus RNA. Satellite RNAs are divided into three broad groups: large, linear satellite RNAs, small linear satellite RNAs, and small circular satellite RNAs. Satellite viruses and most satellite RNAs are not essential for any stage of the infection cycle of the HV, but a few satellite RNAs have a role in the infection cycle of the HV, such as in insect transmission or enhanced HV movement (Simon et al. 2004; Taliansky et al. 2000).

\section{Satellite viruses.}

Satellite viruses have not been examined to determine what effects their RNA sequences might have on host responses. Rather, work on these subviral pathogens has focused on determining the effects they or the expression of their capsid proteins might have on either the HV accumulation or the pathogenicity induced by the $\mathrm{HV}$ in a given host (Mandadi and

Corresponding author: Peter Palukaitis; E-mail: scripath1@yahoo.co.uk

○ 2016 The American Phytopathological Society
Scholthof 2012, 2015; Mandadi et al. 2014). With regard to their noncoding sequences, work has been limited largely to what effects these sequences have on translation of the satellite virus RNAs (Gazo et al. 2004; Meulewaeter et al. 1998; van Lipzig et al. 2001, 2002). The satellite virus of Tobacco mosaic virus has been used as a satellite virus-induced gene silencing system for the silencing of endogenous plant genes (Gosselé et al. 2002). Otherwise, there are no other known roles for satellite viruses functioning as noncoding RNAs.

\section{Large, linear satellite RNAs.}

The large ( 800 to $1,500 \mathrm{nt}$ ) linear satellite RNAs all encode a protein, which in the case of those associated with HV that are members of the genus Nepovirus is required for the replication of the satellite RNA (Briddon et al. 2012; Hu et al. 2009; Roossinck et al. 1992). The large, linear satellite RNA associated with Bamboo mosaic virus (a member of the genus Potexvirus) encodes a protein that is required for efficient systemic movement of the satellite RNA but not for its replication (Hu et al. 2009). While this satellite RNA and its HV have been used as a dual gene silencing vector system to induce RNA silencing of target genes in both a monocotyledonous plant (Brachypodium distachyon) and a dicotyledonous plant (Nicotiana benthamiana) (Liou et al. 2014), none of these large, linear satellite RNAs have been examined for roles of their RNA sequences in affecting host responses. By contrast, the various 895- to 903-nt satellite RNAs of Groundnut rosette virus (a member of the genus Umbravirus) have up to five open reading frames, although none of these appears to encode any proteins required for their infection or any known properties associated with these satellite RNAs (Taliansky and Robinson 1997a). These properties include alteration in symptom responses (including bright yellow-blotch mosaic symptoms, dark-green leaves, and stunting) and reducing the HV accumulation by more than 10-fold (Taliansky and Robinson 1997b). The ability to suppress the accumulation of $\mathrm{HV}$ was associated with the $5^{\prime} 280 \mathrm{nt}$ of the NM3c satellite RNA (Taliansky and Robinson 1997a), and transgenic expression of this region in $N$. benthamiana also reduced the accumulation of the HV (Taliansky et al. 1998a). The mechanisms of these various noncoding RNA-mediated responses are unknown.

\section{Small, circular satellite RNAs.}

The small (220 to $388 \mathrm{nt}$ ) circular satellite RNAs all have a high degree of internal base pairing, similar to viroids, but rely on a HV for their replication and, usually, also for their encapsidation. Those small, circular satellite RNAs associated with $\mathrm{HV}$ that are members of the genus Sobemovirus are packaged as circular RNAs, while those small satellite RNAs associated with viruses that are members of the genera Nepovirus or Polerovirus are packaged as linear RNAs but form a circular RNA in planta 
during replication (Briddon et al. 2012). With one exception (AbouHaidar et al. 2014), the small, circular RNAs are not translated (Briddon et al. 2012; Hu et al. 2009; Roossinck et al. 1992). These satellite RNAs generally either reduce or have no effect on the accumulation of their HV but can affect the symptoms induced by the associated HV, similar to small, linear satellite RNAs (Roossinck et al. 1992). How these effects occur has not been established, but historically, reduced virus accumulation was thought to be by competition between the satellite RNA and the HV during replication (Kaper 1982).

\section{Small, linear satellite RNAs.}

The small (<700 nt) linear satellite RNAs do not encode any proteins but usually have a high percent of base-pairing in their structures. Originally, this was thought to be for protection from ubiquitous nucleases (Francki 1985; Roossinck et al. 1992), but it is now considered to provide (partial) protection from these molecules being targeted by the RNA silencing system (Wang et al. 2004a). Some of these noncoding satellite RNA species show the broadest range of effects on the host and the HV. Small, linear satellite RNAs have one of three effects on the symptoms induced by their HV: attenuate the symptoms, exacerbate the symptoms, or have no effects on the symptoms $(\mathrm{Hu}$ et al. 2009; Roossinck et al. 1992).

\section{Small satellite RNA-mediated enhancement of pathogenicity.}

Exacerbation of the symptoms is less common but has been studied in detail, in particular, for several satellites of Cucumber mosaic virus (CMV) and, also, for Turnip crinkle virus (TCV) and its chimeric satellite RNA C (satC). The 356-nt TCV satC contains $189 \mathrm{nt}$ of the smaller (194 nt) TCV satD for its $5^{\prime}$ half and $166 \mathrm{nt}$ very similar to the HV $3^{\prime}$ terminal nontranslated region for its $3^{\prime}$ half (Simon and Howell 1986; Simon et al. 2004). TCV satC reduced the accumulation of its HV by 25 to $50 \%$ in both plants and protoplasts (Simon et al. 2004), yet, at the same time, the presence of satC enhanced the rate of cellto-cell and long-distance movement and intensified the HVinduced disease symptoms ( $\mathrm{Li}$ and Simon 1990; Zhang and Simon 2003). These effects were shown to be due to satC preventing TCV virion formation, resulting in accumulation of free capsid protein (Zhang and Simon 2003). The capsid protein of TCV was shown to be an RNA silencing suppressor (RSS) (Qu et al. 2003; Thomas et al. 2003), and the free capsid protein was a stronger RSS than the virion-associated capsid protein in Arabidopsis thaliana, potentially resulting in more RNA silencing suppression in the presence of either a capsid protein mutant defective for virion formation or satC (Zhang and Simon 2003). However, this effect of satC may not be related directly to a role in RNA silencing, since the RNA silencing Dicer-like nucleases DCL2 and DCL4 were not required for the reduction in TCV RNA accumulation mediated by satC in A. thaliana (Manfre and Simon 2008).

In general, the satellite RNAs of CMV either attenuate the symptoms induced by their $\mathrm{HV}$ or they have no effects on the symptoms, depending on both the satellite RNA isolate and the host (Cillo et al. 2007; Hu et al. 2009; Roossinck et al. 1992). However, in a few specific cases, some satellites RNAs of CMV have quite deleterious effects on the host, including induction of yellow chlorosis in tobacco (Nicotiana tabacum) (Palukaitis 1988; Takanami 1981), in other Nicotiana spp. (Masuta et al. 1993; Schwach et al. 2005; Takanami 1981), or in pepper (Capsicum annuum) (Choi et al. 2011; Masuta et al. 1988), induction of yellow-leaf (Palukaitis 1988) or white-leaf (Gonsalves et al. 1982) chlorosis in tomato (Solanum lycopersicum), and induction of necrosis in tomato (Kaper and Waterworth 1977; Takanami 1981) and its wild relatives (Cillo et al. 2007).
Differences in these phenotypes have been mapped to one or a few nucleotide changes in specific regions of these noncoding RNAs (Devic et al. 1990; Jaegle et al. 1990; Kuwata et al. 1991; Masuta and Takanami 1989; Sleat and Palukaitis 1990a, 1992; Zhang et al. 1994), although the tomato-necrosis phenotype could be affected by distal (Wu and Kaper 1992) and adjacent (Sleat et al. 1994) regions in the satellite RNA molecule as well as the genotype of the host (Cillo et al. 2007), and the chlorosis phenotype could be affected by the host and HV sequence (Palukaitis 1988; Sleat and Palukaitis 1990b). How do these noncoding satellite RNAs induce such profound changes in plants?

\section{Small satellite RNA-mediated chlorosis induction in tobacco.}

The first indication that RNA silencing might be involved came from experiments by Wang and colleagues (2004a), showing that the yellow-chlorosis phenotype was greatly attenuated when CMV plus the Y-satRNA were inoculated to tobacco plants expressing the RSS of the potyvirus Tobacco etch virus (TEV) HC-Pro. CMV and Y-satRNA accumulation actually were stimulated by the presence of the HC-Pro, thus eliminating negative effects on either accumulation by the expression of the HC-Pro. The latter was similar to what had been shown before during viral synergy occurring in mixed infections by potyviruses and CMV (Poolpol and Inouye 1986; Pruss et al. 1997; Sano and Kojima 1989; Wang et al. 2002, 2004b) although, in the first report of the TEV HCPro expressed in a transgenic tobacco plant (Pruss et al. 1997), CMV was enhanced in accumulation while the associated, uncharacterized satellite RNA was suppressed! Thus, as in many other interactions giving rise to specific and novel phenotypes, the host, the particular satellite RNA, and the HV all have some roles that also need to be explained.

Subsequent work involving yellow-chlorosis induction in tobacco, mediated by Y-satRNA, identified a target mRNA encoding a chloroplast protein involved in chlorophyll biosynthesis, magnesium protoporphyrin chelatase subunit 1 (Chll), containing 22-nt complementary to the Y-satRNA (Shimura et al. 2011; Smith et al. 2011). The Chll mRNA was reduced in accumulation during infection by CMV containing Y-satRNA, with a corresponding increase in Chll small interfering RNAs (siRNAs) (Shimura et al. 2011; Smith et al. 2011). Presumably, siRNAs generated from Y-satRNA bound to sequences in Chll and mediated the RNA-induced silencing complex (RISC)-catalyzed cleavage of this mRNA. In both studies, the ends of the siRNAs generated from the Chll mRNA were consistent with the expected cleavage site (Shimura et al. 2011; Smith et al. 2011). Transgenic tobacco plants expressing the target site of the Chll mRNA also showed yellow-chlorosis symptoms upon infection by CMV plus Y-satRNA, while transgenic tobacco plants expressing a mutant form of the Chll mRNA target site, with nine base changes disrupting basepairing with Y-satRNA, did not (Smith et al. 2011). Similarly, transgenic $N$. benthamiana plants expressing a hairpin construct of the Y-satRNA also induced a weak chlorosis, correlating with a lesser decrease of Chll accumulation (Shimura et al. 2011). Chll genes from other Nicotiana species, which did not exhibit yellow chlorosis when infected by CMV and Y-satRNA, all showed differences in sequence in this 22-nt region (Smith et al. 2011), as did the Chll genes in tomato and A. thaliana (Shimura et al. 2011). Mutation of Y-satRNA to sequences complementary to the Chll sequences present in tomato or A. thaliana and infection of those plants by CMV and the mutated Y-satRNAs resulted in yellow-chlorosis induction in both plant species and a reduction in the levels of Chll mRNA. On the other hand, mutated Y-satRNA could no longer induce yellow chlorosis on 
either $N$. benthamiana or pepper and did not alter the levels of accumulation of Chll mRNA in those plants (Shimura et al. 2011). The sequences of smaller satellite RNAs of CMV involved in induction of various forms of chlorosis on tobacco or tomato are located in a different region of those satellite RNAs and, thus, are not complementary to the Chll mRNA (Zhang et al. 1994); however, Smith et al. (2011) identified a 21-nt sequence from the pathogenicity region of the B2-satRNA and WL3-satRNA, both capable of inducing yellow chlorosis in tobacco (Zhang et al. 1994), in mRNA sequences of the tobacco gene encoding glycolate oxidase. Glycolate oxidase is involved in photorespiration and downregulation of this gene resulted in yellow chlorosis (Yamaguchi and Nishimura 2000). Thus, other forms of chlorosis induction by other satellite RNAs may also be caused by siRNAs generated from those satellite RNAs mediating the cleavage of other mRNAs involved in maintaining chlorophyll levels.

\section{Small satellite RNA-mediated necrosis induction in tomato.}

The induction of necrosis in tomato by the D-satellite RNA (D-satRNA) of CMV involved various features of a plant cell death (PCD) response in infected phloem or cambium cells $(\mathrm{Xu}$ and Roossinck 2000; Xu et al. 2004) and this correlated with the accumulation in those tissues of the minus-strand of the D-satRNA (Xu and Roossinck 2000). (The encapsidated strand is referred to as the plus strand, and the minus strand is generated in large quantities during replication as accumulating doublestranded RNA [Habili and Kaper 1981]). The minus strand had previously been implicated as the elicitor of the necrosis response, after part or all of the minus-strand D-satRNA but not plus-strand D-satRNA was expressed in tomato from a Potato virus $X$ vector (Taliansky et al. 1998b). Multiple defense responses also were induced by CMV plus D-satRNA, which were not induced by CMV alone, yet the plants still exhibited PCD and systemic necrosis (Xu et al. 2003). Transcriptome analysis of tomato plants infected by CMV plus D-satRNA versus a nonnecrogenic mutant of D-satRNA (Dm-satRNA) identified 401 changes in gene expression, including several genes involved in ethylene synthesis and ethylene-induced defense responses (Irian et al. 2007). Increases in the levels of expression of mRNAs encoding ACC oxidase 1, ethylene-inducible pathogenesis-related proteins, and ethylene response transcription factors were confirmed by Northern blot hybridization (Irian et al. 2007). Ethylene-insensitive mutant $(\mathrm{Nr})$ tomato plants infected with CMV and D-satRNA showed an inhibition of epinasty and a delay in systemic necrosis, with limited PCD of the vascular cells, while application of an inhibitor of ethylene function, sodium thiosulfate, also caused similar effects (Irian et al. 2007), confirming the role of ethylene in the development of epinasty, PCD, and systemic necrosis induced by the D-satRNA. How the minus strand of the D-satRNA causes an increase in ethylene biosynthesis and defense responses is not understood. Whether the noncoding RNA leads to alterations in expression or function of transcription factors or upstream signaling kinases by either affecting their translation or binding to a regulatory gene mRNA and facilitating RISC-mediated cleavage of that RNA remains to be established.

\section{Small satellite RNA attenuation of pathogenicity.}

The ability of satellite RNAs to reduce the intensity of symptoms induced by their HV generally coincided with a reduction in the level of accumulation of the HV RNAs (Gal-On et al. 1995; Jacquemond and Leroux 1982; Kaper and Tousignant 1977; Liao et al. 2007; McGarvey et al. 1994; Mossop and Francki 1979), although there were a number of exceptions to this, notably involving the related cucumovirus Tomato aspermy virus as the HV in place of CMV (Masuta et al. 1989; McGarvey et al. 1994; Moriones et al. 1992; Mossop and Francki 1979). This led to a model in which the satellite RNAs were competing with their HV for the replicase, resulting in less virus accumulation and, thus, less disease (Kaper 1982). This model was based on a similar earlier one for defective interfering (DI) RNAs of animal viruses competing with their HV for limited quantities of viral replicase also reducing the titer of those viruses (Huang and Baltimore 1977). This also became the prevailing view regarding plant virus DI RNAs (Jones et al. 1990; Russo et al. 1994). However, there were also exceptions to this generalization (Chang et al. 1995; Havelda et al. 1998; Qiu et al. 2001) and work this century showed that the DI RNAs of a plant virus can affect the HV through RNA silencing rather than direct competition for the viral replicase (Havelda et al. 2005; Szittya et al. 2002). The noncoding DI RNA, having the same sequence as parts of the HV from which it was generated by the replicase, by either skipping along its template or jumping to other HV RNA molecules, contained a high degree of secondary structure, making these molecules poorly accessible to siRNAs generated from the DI RNAs by Dicer-like proteins (Szittya et al. 2002). (The template for the Dicer-like proteins probably was double-stranded RNAs generated from the DI RNAs during replication.) However, these siRNAs generated from the DI RNAs could bind to and saturate the HV RSS, reducing its ability to bind to siRNAs generated from the HV RNA, and also target the identical sequences present in the HV genome, which were not as structured as the DI RNAs, both leading to degradation of the HV RNAs and reduced pathogenicity in plants (Havelda et al. 2005; Szittya et al. 2002). Could RNA silencing also be involved in the mechanism of satellite RNA-mediated attenuation of virus disease?

\section{Small satellite RNA as a counter of RNA silencing suppression.}

Several RSS have been shown to be pathogenicity factors, functioning as such by inhibiting the microRNA (miRNA)mediated turnover of transcription factors (Shimura and Pantaleo 2011; Wang et al. 2012). In the case of the CMV RSS, the $2 b$ protein of a severe CMV strain (Fny) but not of mild strains ( $Q$ or LS) was shown to interfere with the turnover of mRNAs encoding various transcription factors as well as their regulatory miRNAs, resulting in a severe disease phenotype in A. thaliana (Lewsey et al. 2007; Zhang et al. 2006). This was also generally true in tomato plants (Solanum lycopersicum) infected by either FnyCMV alone (Feng et al. 2009, 2011, 2012) or Fny-CMV versus LS-CMV (Cillo et al. 2009); however, in tomato, infection by LSCMV perturbed miRNA-mediated turnover of some transcription factors, consistent with the mild symptoms generated by LSCMV in tomato (Cillo et al. 2009). Interestingly, coinfection of Fny-CMV and an attenuating satellite RNA reduced the effect of the $\mathrm{HV}$ on the accumulation of most of the transcription factor examined as well on the associated miRNAs (Cillo et al. 2009; Feng et al. 2012), similar to the effects of deleting the $2 b$ gene from Fny-CMV (Feng et al. 2011, 2012). The conclusion that the $2 \mathrm{~b}$ RSS was responsible for at least some, if not most, of the developmental defects associated with CMV infection led to the idea that the satellite RNA could act as a high level source of siRNAs competing with miRNAs and other siRNAs for binding to the $2 \mathrm{~b}$ protein. This would result in the $2 \mathrm{~b}$ protein being prevented from binding miRNAs and an attenuation of symptoms induced by the $2 b$ protein inhibiting the miRNA-mediated regulation of developmental mRNAs (Shen et al. 2015). Some support for this model came from experiments involving the ability of the Y-satRNA to interfere with the CMV 2b- and Tomato bushy stunt virus (TBSV) P19-mediated suppression of transientlyexpressed $\beta$-glucuronidase (GUS) silencing by a GUS hairpin transcript in $N$. benthamiana. The TBSV P19 was shown to 
contain predominantly Y-satRNA siRNAs rather than GUShairpin RNAs, as was observed in the absence of Y-satRNA in the inoculum (Shen et al. 2015). In addition, while CMV in tobacco was also able to up-regulate the expression of several miRNA target genes, CMV plus the Y-satRNA did not do so (Shen et al. 2015), supporting the previous conclusions from work done in A. thaliana and tomato (Cillo et al. 2009; Feng et al. 2012; Lewsey et al. 2007; Zhang et al. 2006). Thus, satellite RNAs may neutralize part of the function of the HV RSS or that of any coinfecting virus for which the RSS also binds siRNAs. However, not all RSS bind small RNAs, and viruses with defective RSS were found to be pathogenic in silencing-defective $A$. thaliana (Deleris et al. 2006; Diaz-Pendon et al. 2007; Garcia-Ruiz et al. 2010; Wang et al. 2010). Similarly, there is a strong plant genotype and satellite sequence effect on the nature of the phenotype observed (Cillo et al. 2007). Thus, some additional factor may be necessary to explain the effects of satellite RNAs on symptoms than just competition for binding of miRNAs.

\section{Small satellite RNA and interference in accumulation of specific HV RNAs.}

In the case of TBSV DI RNAs (Scholthof et al. 1995) and CMV satellite RNAs (Feng et al. 2012; Hou et al. 2011; Liao et al. 2007), the presence of the extraviral RNA resulted in a greater decrease in accumulation of specific HV subgenomic RNAs than of the various HV genomic RNAs. In the case of the CMV SD-satRNA, this was proposed as a method by which the satellite RNA could reduce the level of $2 \mathrm{~b}$ protein accumulation, leading to a reduction in symptoms (Hou et al. 2011). Subsequently, it was suggested that siRNAs derived from the satellite RNA could reduce the level of the 2b-encoding CMV RNA $4 \mathrm{~A}$ by targeting specific sequences in the $3^{\prime}$ nontranslated region, although only CMV RNA 1 was actually affected directly thus experimentally (Zhu et al. 2011). Interestingly, those researchers also showed that the satellite siRNA-mediated degradation of RNA 1 required RDR6 and was inhibited by the $2 b$ protein.

How else could the satellite RNA specifically decrease the levels of CMV RNA 4A? Since the same sequences as present in RNA 4A are contained in the genomic RNA 2, then presumably, the satellite RNA would have to partially inhibit the synthesis of RNA 4A from the core promoter on the minusstrand RNA 2 template (Sivakumaran et al. 2002). While no complementarity of sequence has been described between CMV satellite RNAs and the RNA 4A core promoter, such sequence complementarities were described between the $5^{\prime}$ nontranslated region of CMV RNAs 1 and 2 and a satellite RNA (Rezaian et al. 1985) that could, potentially, interfere with the reproduction or translation of those HV RNAs, leading to depression of the HV RNA accumulation. On the other hand, the specific reduction in RNA 4A accumulation also could be a reflection of the fact that this subgenomic RNA is either poorly or not encapsidated into virions (Feng et al. 2006) and, thus, this RNA may be less protected from other effects on the CMV RNAs manifested by coinfection with a satellite RNA.

\section{Satellite RNA and the reduction in HV accumulation.}

The complete disruption of the link between satellite RNA accumulation and the reduction in HV accumulation was shown by experiments examining the effect of synergy between viruses on virus accumulation and the effect of satellite RNA in this process. Specifically, infection of cucurbits by either of two strains of CMV (LS and Fny) and either of two potyviruses resulted in an enhanced pathogenicity and an increase in accumulation of CMV but not of the potyviruses (Wang et al. 2002). (This is now generally attributed to the effects of the potyvirus RSS acting against components of the RNA silencing machinery that are not [effectively] targeted by the CMV
RSS and further reducing host effects on CMV accumulation [Palukaitis 2011; Palukaitis and MacFarlane 2006].) By contrast, the addition of satellite RNA to the mixture resulted in an increase in accumulation of both the HV and the satellite RNAs (Wang et al. 2002). This is not consistent with a model in which enhanced satellite RNA accumulation would lead to suppression of the HV by competition for the replicase or by suppressing the production of the $2 \mathrm{~b}$ RSS. However, it is consistent with a model in which large quantities of siRNAs, generated from the satellite double-stranded RNA during normal replication of CMV plus its satellite RNAs, would bind to and saturate the CMV RSS, as also suggested by Shen et al. (2015). This could then result in large quantities of CMV siRNAs being available to bind to AGO proteins in the RISC complex and to target the CMV RNAs, leading to a reduction in the level of accumulated CMV RNAs, as was shown for specific satellite siRNAs bound to several AGO proteins (Zhu et al. 2011). In the case of the synergy experiments, the potyvirus RSS could prevent the latter from happening. However, there must also be host effects on this process, since in tomato, the combination of CMV, a satellite RNA, and a potyvirus did not result in enhanced accumulation of both the CMV and its satellite RNA (Mascia et al. 2010). In addition, while satellite RNAs have been shown to reduce the accumulation of $\mathrm{HV}$ in tobacco and, to a lesser extent, in zucchini squash (Cucurbita pepo) (Jacquemond and Leroux 1982; Kaper and Tousignant 1977), in A. thaliana, there was no reduction of genomic CMV RNA accumulation by the associated satellite RNA (Hou et al. 2011), while in N. benthamiana, reduction occurred only to a small extent (Hou et al. 2011; Shen et al. 2015), potentially depending on the combination of CMV strain and satellite RNA isolate. Thus, there are also HVspecific, satellite RNA-specific, and host-specific effects of still unknown aspects affecting the attenuation of symptoms and the inhibition of virus accumulation. The challenge remains to separate and identify these components.

\section{ACKNOWLEDGMENTS}

This work is dedicated to the memory of those colleagues and friends whose work on satellite RNAs has brought light to a small, highlystructured, dark corner of the universe: Richard Francki, Mireille Jacquemond, Mike Mayo, Irving Schneider, and Bob Symons. This work was supported in part by grant number NRF-2013R1A2A2A01016282 from the Korean National Research Foundation.

\section{LITERATURE CITED}

AbouHaidar, M. G., Venkataraman, S., Golshani, A., Liu, B., and Ahmad, T. 2014. Novel coding, translation, and gene expression of a replicating covalently closed circular RNA of 220 nt. Proc. Natl. Acad. Sci. U.S.A. 111:14542-14547.

Briddon, R. W., Ghabrial, S., Lin, N.-S., Palukaitis, P., Scholthof, K.-B. G., and Vetten, H.-J. 2012. Satellite and other virus-dependent nucleic acids. Pages 1211-1219 in: Virus Taxonomy. Classification and Nomenclature of Viruses. Ninth Report of the International Committee on Taxonomy of Viruses. A. M. Q. King, M. J. Adams, E. B. Carstens, and E. J. Lefkowitz, eds. Elsevier Academic Press, San Diego, CA, U.S.A.

Chang, Y. C., Borja, M., Scholthof, H. B., Jackson, A. O., and Morris, T. J. 1995. Host effects and sequences essential for accumulation of defective interfering RNAs of cucumber necrosis and tomato bushy stunt tombusviruses. Virology 210:41-53.

Choi, S. K., Jeon, Y. W., Yoon, J. Y., and Choi, J. K. 2011. Characterisation of a satellite RNA of Cucumber mosaic virus that induces chlorosis in Capsicum annuum. Virus Genes 43:111-119.

Cillo, F., Mascia, T., Pasciuto, M. M., and Gallitelli, D. 2009. Differential effects of mild and severe Cucumber mosaic virus strains in the perturbation of MicroRNA-regulated gene expression in tomato map to the $3^{\prime}$ sequence of RNA 2. Mol. Plant-Microbe Interact. 22: 1239-1249.

Cillo, F., Pasciuto, M. M., De Giovanni, C., Finetti-Sialer, M. M., Ricciardi, L., and Gallitelli, D. 2007. Response of tomato and its wild relatives in 
the genus Solanum to cucumber mosaic virus and satellite RNA combinations. J. Gen. Virol. 88:3166-3176.

Deleris, A., Gallego-Bartolome, J., Bao, J., Kasschau, K. D., Carrington, J. C., and Voinnet, O. 2006. Hierarchical action and inhibition of plant Dicer-like proteins in antiviral defense. Science 313:68-71.

Devic, M., Jaegle, M., and Baulcombe, D. 1990. Cucumber mosaic virus satellite RNA (strain Y): Analysis of sequences which affect systemic necrosis on tomato. J. Gen. Virol. 71:1443-1449.

Diaz-Pendon, J. A., Li, F., Li, W. X., and Ding, S. W. 2007. Suppression of antiviral silencing by cucumber mosaic virus $2 \mathrm{~b}$ protein in Arabidopsis is associated with drastically reduced accumulation of three classes of vira small interfering RNAs. Plant Cell 19:2053-2063.

Feng, J., Lai, L., Lin, R., Jin, C., and Chen, J. 2012. Differential effects of Cucumber mosaic virus satellite RNAs in the perturbation of microRNAregulated gene expression in tomato. Mol. Biol. Rep. 39:775-784.

Feng, J., Liu, X., Lai, L., and Chen, J. 2011. Spatio-temporal expression of miRNAs in tomato tissues upon Cucumber mosaic virus and Tomato aspermy virus infections. Acta Biochim. Biophys. Sin. (Shanghai) 43:258266.

Feng, J., Wang, K., Liu, X., Chen, S., and Chen, J. 2009. The quantification of tomato microRNAs response to viral infection by stem-loop real-time RT-PCR. Gene 437:14-21.

Feng, J. L., Chen, S. N., Tang, X. S., Ding, X. F., Du, Z. Y., and Chen, J. S. 2006. Quantitative determination of Cucumber mosaic virus genome RNAs in virions by real-time reverse transcription-polymerase chain reaction. Acta Biochim. Biophys. Sin. (Shanghai) 38:669-676.

Francki, R. I. B. 1985. Plant virus satellites. Annu. Rev. Microbiol. 39: 151-174.

Gal-On, A., Kaplan, I., and Palukaitis, P. 1995. Differential effects of satellite RNA on the accumulation of cucumber mosaic virus RNAs and their encoded proteins in tobacco vs zucchini squash with two strains of CMV helper virus. Virology 208:58-66.

Garcia-Ruiz, H., Takeda, A., Chapman, E. J., Sullivan, C. M., Fahlgren, N., Brempelis, K. J., and Carrington, J. C. 2010. Arabidopsis RNAdependent RNA polymerases and dicer-like proteins in antiviral defense and small interfering RNA biogenesis during Turnip mosaic virus infection. Plant Cell 22:481-496.

Gazo, B. M., Murphy, P., Gatchel, J. R., and Browning, K. S. 2004. A novel interaction of Cap-binding protein complexes eukaryotic initiation factor (eIF) $4 \mathrm{~F}$ and eIF(iso) $4 \mathrm{~F}$ with a region in the $3^{\prime}$-untranslated region of satellite tobacco necrosis virus. J. Biol. Chem. 279:13584-13592.

Gonsalves, D., Provvidenti, R., and Edwards, M. C. 1982. Tomato white leaf: The relation of an apparent satellite RNA and cucumber mosaic virus. Phytopathology 72:1533-1538.

Gosselé, V., Faché, I., Meulewaeter, F., Cornelissen, M., and Metzlaff, M. 2002. SVISS - A novel transient gene silencing system for gene function discovery and validation in tobacco plants. Plant J. 32:859-866.

Habili, N., and Kaper, J. M. 1981. Cucumber mosaic virus-associated RNA 5. VII. Double-stranded form accumulation and disease attenuation in tobacco. Virology 112:250-261.

Havelda, Z., Hornyik, C., Válóczi, A., and Burgyán, J. 2005. Defective interfering RNA hinders the activity of a tombusvirus-encoded posttranscriptional gene silencing suppressor. J. Virol. 79:450-457.

Havelda, Z., Szittya, G., and Burgyán, J. 1998. Characterization of the molecular mechanism of defective interfering RNA-mediated symptom attenuation in tombusvirus-infected plants. J. Virol. 72:6251-6256.

Hou, W. N., Duan, C. G., Fang, R. X., Zhou, X. Y., and Guo, H. S. 2011. Satellite RNA reduces expression of the $2 \mathrm{~b}$ suppressor protein resulting in the attenuation of symptoms caused by Cucumber mosaic virus infection. Mol. Plant Pathol. 12:595-605.

Hu, C. C., Hsu, Y. H., and Lin, N. S. 2009. Satellite RNAs and satellite viruses of plants. Viruses 1:1325-1350.

Huang, A. S., and Baltimore, D. 1977. Defective interfering animal viruses Pages 73-116 in: Comprehensive Virology, Vol. 10, H. Fraenkel-Conrat and R. R. Wagner, eds. Plenum Press, New York.

Irian, S., Xu, P., Dai, X., Zhao, P. X., and Roossinck, M. J. 2007. Regulation of a virus-induced lethal disease in tomato revealed by LongSAGE analysis. Mol. Plant-Microbe Interact. 20:1477-1488.

Jacquemond, M., and Leroux, J. P. 1982. 'ARN satellite du virus de la mosaique du concombre II. Etude de la relation virus-ARN satellite chez diers hotes. Agronomie 2:55-62.

Jaegle, M., Devic, M., Longstaff, M., and Baulcombe, D. 1990. Cucumber mosaic virus satellite RNA (Y strain): Analysis of sequences which affect yellow mosaic symptoms on tobacco. J. Gen. Virol. 71:19051912

Jones, R. W., Jackson, A. O., and Morris, T. J. 1990. Defective-interfering RNAs and elevated temperatures inhibit replication of tomato bushy stunt virus in inoculated protoplasts. Virology 176:539-545.
Kaper, J. M. 1982. Rapid synthesis of double-stranded cucumber mosaic virus-associated RNA 5: Mechanism controlling viral pathogenesis? Biochem. Biophys. Res. Commun. 105:1014-1022.

Kaper, J. M., and Tousignant, M. E. 1977. Cucumber mosaic virusassociating RNA 5. I. Role of host plant and helper strain in determining amount of associated RNA 5 with virions. Virology 80:186-195.

Kaper, J. M., and Waterworth, H. E. 1977. Cucumber mosaic virus associated RNA 5: Causal agent for tomato necrosis. Science 196:429-431.

Kuwata, S., Masuta, C., and Takanami, Y. 1991. Reciprocal phenotype alterations between two satellite RNAs of cucumber mosaic virus. J. Gen. Virol. 72:2385-2389.

Lewsey, M., Robertson, F. C., Canto, T., Palukaitis, P., and Carr, J. P. 2007 Selective targeting of miRNA-regulated plant development by a viral counter-silencing protein. Plant J. 50:240-252.

Li, X. H., and Simon, A. E. 1990. Symptom intensification on cruciferous hosts by the virulent sat-RNA of turnip crinkle virus. Phytopathology 80 : 238-242.

Liao, Q., Zhu, L., Du, Z., Zeng, R., Peng, J., and Chen, J. 2007. Satellite RNA-mediated reduction of cucumber mosaic virus genomic RNAs accumulation in Nicotiana tabacum. Acta Biochim. Biophys. Sin. (Shanghai) 39:217-223.

Liou, M. R., Huang, Y. W., Hu, C. C., Lin, N. S., and Hsu, Y. H. 2014. A dual gene-silencing vector system for monocot and dicot plants. Plant Biotechnol. J. 12:330-343.

Mandadi, K. K., Pyle, J. D., and Scholthof, K.-B. G. 2014. Comparative analysis of antiviral responses in Brachypodium distachyon and Setaria viridis reveals conserved and unique outcomes among C3 and C4 plant defenses. Mol. Plant-Microbe Interact. 27:1277-1290.

Mandadi, K. K., and Scholthof, K.-B. G. 2012. Characterization of a viral synergism in the monocot Brachypodium distachyon reveals distinctly altered host molecular processes associated with disease. Plant Physiol. 160:1432-1452.

Mandadi, K. K., and Scholthof, K.-B. G. 2015. Genome-wide analysis of alternative splicing landscapes modulated during plant-virus interactions in Brachypodium distachyon. Plant Cell 27:71-85.

Manfre, A. J., and Simon, A. E. 2008. Importance of coat protein and RNA silencing in satellite RNA/virus interactions. Virology 379:161-167.

Mascia, T., Cillo, F., Fanelli, V., Finetti-Sialer, M. M., De Stradis, A. Palukaitis, P., and Gallitelli, D. 2010. Characterization of the interactions between Cucumber mosaic virus and Potato virus $Y$ in mixed infections in tomato. Mol. Plant-Microbe Interact. 23:1514-1524.

Masuta, C., Komari, T., and Takanami, Y. 1989. Expression of cucumber mosaic virus satellite RNA from cDNA copies in transgenic tobacco plants. Ann. Phytopathological Soc. Jpn. 55:49-55.

Masuta, C., Kuwata, S., and Takanami, Y. 1988. Disease modulation on several plants by cucumber mosaic virus satellite RNA (Y strain). Ann. Phytopathological Soc. Jpn. 54:332-336.

Masuta, C., Suzuki, M., Kuwata, S., Takanami, Y., and Koiwai, A. 1993. Yellow mosaic symptoms induced by $\mathrm{Y}$ satellite RNA of cucumber mosaic virus is regulted by a single incompletely dominant gene in wild Nicotiana species. Phytopathology 83:411-413.

Masuta, C., and Takanami, Y. 1989. Determination of sequence and structural requirements for pathogenicity of a cucumber mosaic virus satellite RNA (Y-satRNA). Plant Cell 1:1165-1173.

McGarvey, P. B., Montasser, M. S., and Kaper, J. M. 1994. Transgenic tomato plants expressing satellite RNA are tolerant to some strains of cucumber mosaic virus. J. Am. Soc. Hortic. Sci. 119:642-647.

Meulewaeter, F., Danthinne, X., Van Montagu, M., and Cornelissen, M. 1998. 5' - and 3'-sequences of satellite tobacco necrosis virus RNA promoting translation in tobacco. Plant J. 14:169-176.

Moriones, E., Diaz, I., Rodriguez-Cerezo, E., Fraile, A., and GarcíaArenal, F. 1992. Differential interactions among strains of tomato aspermy virus and satellite RNAs of cucumber mosaic virus. Virology 186:475-480.

Mossop, D. W., and Francki, R. I. B. 1979. Comparative studies on two satellite RNAs of cucumber mosaic virus. Virology 95:395-404.

Palukaitis, P. 1988. Pathogenicity regulation by satellite RNAs of cucumber mosaic virus: Minor nucleotide sequence changes alter host responses. Mol. Plant-Microbe Interact. 1:175-181

Palukaitis, P. 2011. The road to RNA silencing is paved with plant-virus interactions. Plant Pathol. J. 27:197-206.

Palukaitis, P., and MacFarlane, S. A. 2006. Viral counter-defense molecules. Pages 165-185 in: Natural Resistance Mechanisms of Plants to Viruses. G. Loebenstein, and J. P. Carr, eds. Springer, Dortrecht, The Netherlands.

Poolpol, P., and Inouye, T. 1986. Enhancement of cucumber mosaic virus multiplication by zucchini yellow mosaic virus in doubly infected cucumber plants. Ann. Phytopathological Soc. Jpn. 52:22-30. 
Pruss, G., Ge, X., Shi, X. M., Carrington, J. C., and Vance, V. B. 1997. Plant viral synergism: The potyviral genome encodes a broad-range pathogenicity enhancer that transactivates replication of heterologous viruses. Plant Cell 9:859-868.

Qiu, W., Park, J. W., Jackson, A. O., and Scholthof, H. B. 2001. Retention of a small replicase gene segment in tomato bushy stunt virus defective RNAs inhibits their helper-mediated trans-accumulation. Virology 281:51-60.

Qu, F., Ren, T., and Morris, T. J. 2003. The coat protein of turnip crinkle virus suppresses posttranscriptional gene silencing at an early initiation step. J. Virol. 77:511-522.

Rezaian, M. A., Williams, R. H. V., and Symons, R. H. 1985. Nucleotide sequence of cucumber mosaic virus RNA. 1. Presence of a sequence complementary to part of the viral satellite RNA and homologies with other viral RNAs. Eur. J. Biochem. 150:331-339.

Roossinck, M. J., Sleat, D., and Palukaitis, P. 1992. Satellite RNAs of plant viruses: Structures and biological effects. Microbiol. Rev. 56:265-279.

Russo, M., Burgyán, J., and Martelli, G. P. 1994. Molecular biology of tombusviridae. Adv. Virus Res. 44:381-428.

Sano, Y., and Kojima, M. 1989. Increase in cucumber mosaic virus concentration in Japanese radish plants co-infected with turnip mosaic virus. Ann. Phytopathological Soc. Jpn. 55:296-302.

Scholthof, K. B., Scholthof, H. B., and Jackson, A. O. 1995. The effect of defective interfering RNAs on the accumulation of tomato bushy stunt virus proteins and implications for disease attenuation. Virology 211:324328.

Schwach, F., Vaistij, F. E., Jones, L., and Baulcombe, D. C. 2005. An RNAdependent RNA polymerase prevents meristem invasion by potato virus $\mathrm{X}$ and is required for the activity but not the production of a systemic silencing signal. Plant Physiol. 138:1842-1852.

Shen, W. X., Au, P. C. K., Shi, B. J., Smith, N. A., Dennis, E. S., Guo, H. S., Zhou, C. Y., and Wang, M. B. 2015. Satellite RNAs interfere with the function of viral RNA silencing suppressors. Front. Plant Sci. 6:281.

Shimura, H., and Pantaleo, V. 2011. Viral induction and suppression of RNA silencing in plants. Biochim. Biophys. Acta 1809:601-612.

Shimura, H., Pantaleo, V., Ishihara, T., Myojo, N., Inaba, J., Sueda, K., Burgyán, J., and Masuta, C. 2011. A viral satellite RNA induces yellow symptoms on tobacco by targeting a gene involved in chlorophyll biosynthesis using the RNA silencing machinery. PLoS Pathog. 7: e1002021.

Simon, A. E., and Howell, S. H. 1986. The virulent satellite RNA of turnip crinkle virus has a major domain homologous to the $3^{\prime}$ end of the helper virus genome. EMBO (Eur. Mol. Biol. Organ.) J. 5:3423-3428.

Simon, A. E., Roossinck, M. J., and Havelda, Z. 2004. Plant virus satellite and defective interfering RNAs: New paradigms for a new century. Annu. Rev. Phytopathol. 42:415-437.

Sivakumaran, K., Chen, M. H., Roossinck, M. J., and Kao, C. C. 2002. Core promoter for initiation of Cucumber mosaic virus subgenomic RNA4A. Mol. Plant Pathol. 3:43-52.

Sleat, D. E., and Palukaitis, P. 1990a. Site-directed mutagenesis of a plant viral satellite RNA changes its phenotype from ameliorative to necrogenic. Proc. Natl. Acad. Sci. U.S.A. 87:2946-2950.

Sleat, D. E., and Palukaitis, P. 1990b. Induction of tobacco chlorosis by certain cucumber mosaic virus satellite RNAs is specific to subgroup II helper strains. Virology 176:292-295.

Sleat, D. E., and Palukaitis, P. 1992. A single nucleotide change within a plant virus satellite RNA alters the host specificity of disease induction. Plant J. 2:43-49.

Sleat, D. E., Zhang, L., and Palukaitis, P. 1994. Mapping determinants within cucumber mosaic virus and its satellite RNA for the induction of necrosis in tomato plants. Mol. Plant-Microbe Interact. 7:189-195.

Smith, N. A., Eamens, A. L., and Wang, M. B. 2011. Viral small interfering RNAs target host genes to mediate disease symptoms in plants. PLoS Pathog. 7:e1002022.

Szittya, G., Molnár, A., Silhavy, D., Hornyik, C., and Burgyán, J. 2002. Short defective interfering RNAs of tombusviruses are not targeted but trigger post-transcriptional gene silencing against their helper virus. Plant Cell 14:359-372.

Takanami, Y. 1981. A striking change in symptoms on cucumber mosaic virus-infected tobacco plants induced by a satellite RNA. Virology 109: 120-126.

Taliansky, M. E., and Robinson, D. J. 1997a. Trans-acting untranslated elements of groundnut rosette virus satellite RNA are involved in symptom production. J. Gen. Virol. 78:1277-1285.
Taliansky, M. E., and Robinson, D. J. 1997b. Down-regulation of groundnut rosette virus replication by a variant satellite RNA. Virology 230:228-235.

Taliansky, M. E., Robinson, D. J., and Murant, A. F. 2000. Groundnut rosette disease virus complex: Biology and molecular biology. Adv. Virus Res. 55:357-400.

Taliansky, M. E., Ryabov, E. V., and Robinson, D. J. 1998a. Two distinct mechanisms of transgenic resistance mediated by groundnut rosette virus satellite RNA sequences. Mol. Plant-Microbe Interact. 11:367-374.

Taliansky, M. E., Ryabov, E. V., Robinson, D. J., and Palukaitis, P. 1998b. Tomato cell death mediated by complementary plant viral satellite RNA sequences. Mol. Plant-Microbe Interact. 11:1214-1222.

Thomas, C. L., Leh, V., Lederer, C., and Maule, A. J. 2003. Turnip crinkle virus coat protein mediates suppression of RNA silencing in Nicotiana benthamiana. Virology 306:33-41.

van Lipzig, R., Gultyaev, A. P., Pleij, C. W., van Montagu, M., Cornelissen, M., and Meulewaeter, F. 2002. The 5' and $3^{\prime}$ extremities of the satellite tobacco necrosis virus translational enhancer domain contribute differentially to stimulation of translation. RNA 8:229-236.

van Lipzig, R., Van Montagu, M., Cornelissen, M., and Meulewaeter, F. 2001. Functionality of the STNV translational enhancer domain correlates with affinity for two wheat germ factors. Nucleic Acids Res. 29: 1080-1086.

Wang, M. B., Bian, X. Y., Wu, L. M., Liu, L. X., Smith, N. A., Isenegger, D., Wu, R. M., Masuta, C., Vance, V. B., Watson, J. M., Rezaian, A., Dennis, E. S., and Waterhouse, P. M. 2004a. On the role of RNA silencing in the pathogenicity and evolution of viroids and viral satellites. Proc. Natl. Acad. Sci. U.S.A. 101:3275-3280.

Wang, M. B., Masuta, C., Smith, N. A., and Shimura, H. 2012. RNA silencing and plant viral diseases. Mol. Plant-Microbe Interact. 25: 1275-1285.

Wang, X. B., Wu, Q., Ito, T., Cillo, F., Li, W. X., Chen, X., Yu, J. L., and Ding, S. W. 2010. RNAi-mediated viral immunity requires amplification of virus-derived siRNAs in Arabidopsis thaliana. Proc. Natl. Acad. Sci. U.S.A. 107:484-489.

Wang, Y., Gaba, V., Yang, J., Palukaitis, P., and Gal-On, A. 2002. Characterization of synergy between Cucumber mosaic virus and potyviruses in cucurbit hosts. Phytopathology 92:51-58.

Wang, Y., Lee, K. C., Gaba, V., Wong, S. M., Palukaitis, P., and Gal-On, A. 2004b. Breakage of resistance to Cucumber mosaic virus by co-infection with Zucchini yellow mosaic virus: Enhancement of CMV accumulation independent of symptom expression. Arch. Virol. 149:379-396.

Wu, G., and Kaper, J. M. 1992. Widely separated sequence elements within cucumber mosaic virus satellites contribute to their ability to induce lethal tomato necrosis. J. Gen. Virol. 73:2805-2812.

Xu, P., Blancaflor, E. B., and Roossinck, M. J. 2003. In spite of induced multiple defense responses, tomato plants infected with Cucumber mosaic virus and D satellite RNA succumb to systemic necrosis. Mol. Plant-Microbe Interact. 16:467-476.

Xu, P., Rogers, S. J., and Roossinck, M. J. 2004. Expression of antiapoptotic genes $b c l-x L$ and $c e d-9$ in tomato enhances tolerance to viral-induced necrosis and abiotic stress. Proc. Natl. Acad. Sci. U.S.A. 101:1580515810 .

Xu, P., and Roossinck, M. J. 2000. Cucumber mosaic virus D satellite RNAinduced programmed cell death in tomato. Plant Cell 12:1079-1092.

Yamaguchi, K., and Nishimura, M. 2000. Reduction to below threshold levels of glycolate oxidase activities in transgenic tobacco enhances photoinhibition during irradiation. Plant Cell Physiol. 41:1397-1406.

Zhang, F., and Simon, A. E. 2003. Enhanced viral pathogenesis associated with a virulent mutant virus or a virulent satellite RNA correlates with reduced virion accumulation and abundance of free coat protein. Virology 312:8-13.

Zhang, L., Kim, C. H., and Palukaitis, P. 1994. The chlorosis-induction domain of the satellite RNA of cucumber mosaic virus: Identifying sequences that affect accumulation and the degree of chlorosis. Mol. Plant-Microbe Interact. 7:208-213.

Zhang, X., Yuan, Y. R., Pei, Y., Lin, S. S., Tuschl, T., Patel, D. J., and Chua, N. H. 2006. Cucumber mosaic virus-encoded 2b suppressor inhibits Arabidopsis Argonaute1 cleavage activity to counter plant defense. Genes Dev. 20:3255-3268.

Zhu, H., Duan, C. G., Hou, W. N., Du, Q. S., Lv, D. Q., Fang, R. X., and Guo, H. S. 2011. Satellite RNA-derived small interfering RNA satsiR-12 targeting the $3^{\prime}$ untranslated region of Cucumber mosaic virus triggers viral RNAs for degradation. J. Virol. 85:13384-13397. 